\title{
Expert views on sustainability and technology implementation
}

\section{Working Paper}

Author(s):

Laws, David; Scholz, Roland W.; Shiroyama, Hideaki; Susskind, Lawrence; Suzuki, Tatsuro; Weber, Olaf

Publication date:

2002

Permanent link:

https://doi.org/10.3929/ethz-a-004336165

Rights / license:

In Copyright - Non-Commercial Use Permitted

Originally published in:

Working Paper / UNS 30 


\section{Working Paper}

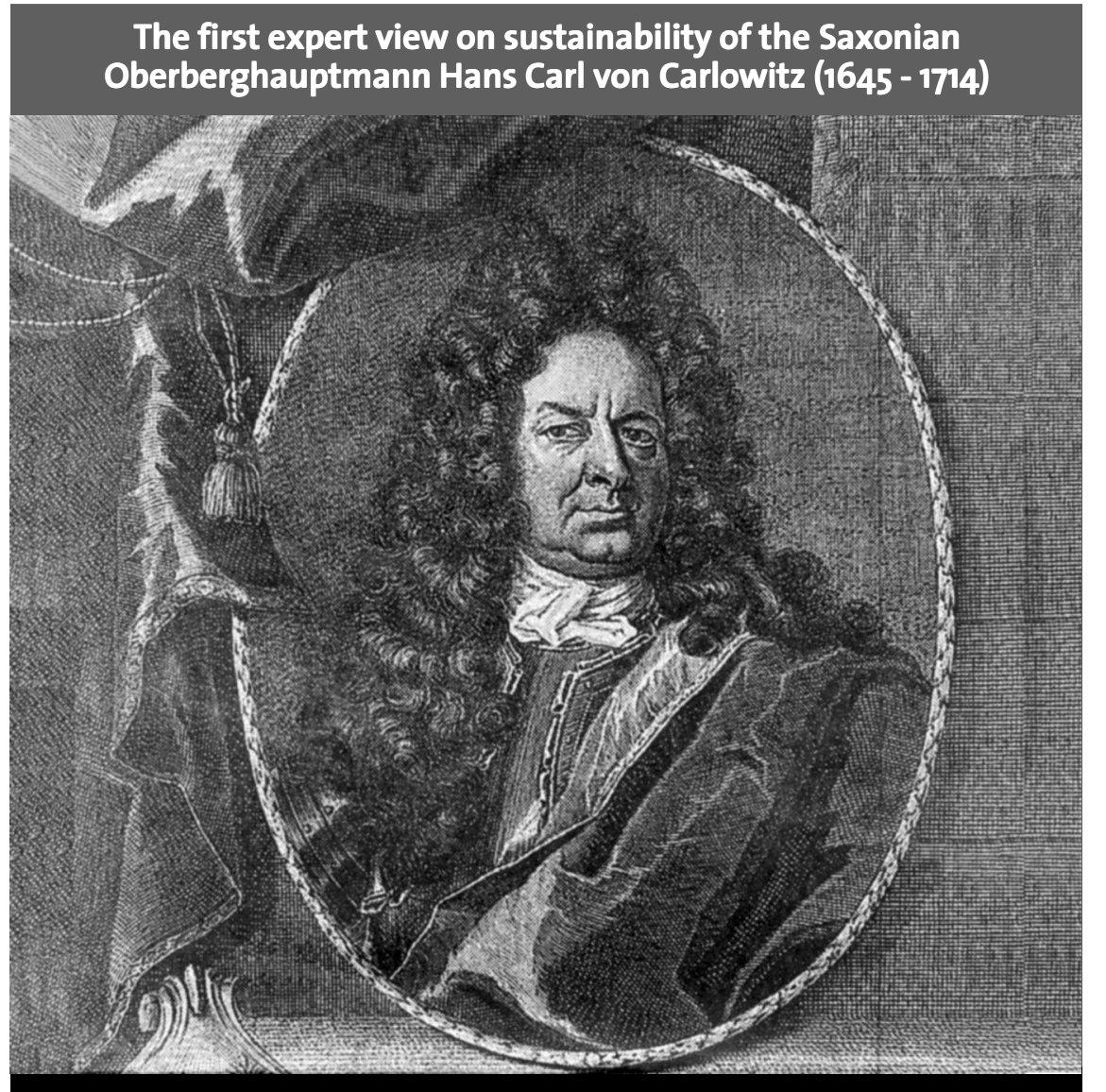

Oberberghauptmann Hans Carl von Carlowitz (1645 - 1714)

$\square$ Expert Views on Sustainability and Technology Implementation

David Laws, Roland W. Scholz, Hideaki Shiroyama, Lawrence Susskind, Tatsuro Suzuki, and Olaf Weber

March 2002

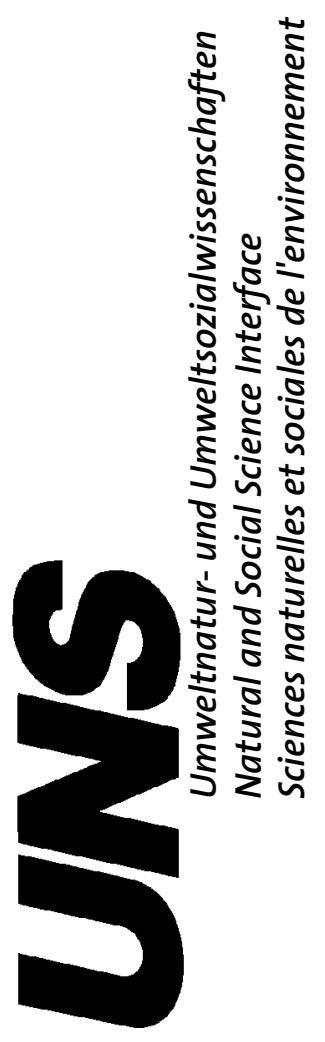




\section{Natural and Social Science Interface (UNS)}

Publisher:

Prof. Dr. Roland W. Scholz

Umweltnatur- und

Umweltsozialwissenschaften (UNS)

ETH Zentrum HAD

Haldenbachstrasse 44

$\mathrm{CH}-8092$ Zürich

Tel. $++41-1-6325892$

Fax ++41-1-63210 29

E-mail:scholz@uns.umnw.ethz.ch

Corresponding authors:

Prof. Dr. David Laws

Environmental Technology and Public Policy Program

Department of Urban Studies and Planning

Massachusetts Institute of Technology

Tel. ++1-617-253-2084

E-mail:dlaws@mit.edu

Prof. Dr. Roland W. Scholz

Umweltnatur- und Umweltsozialwissenschaften

ETH Zentrum HAD

$\mathrm{CH}-8092$ Zürich

Tel. $\quad++41-1-6325892$

Fax ++41-1-63210 29

E-mail: scholz@uns.umnw.ethz.ch

\section{EIH}

Eidgenössische Technische Hochschule Zürich

Swiss Federal Institute of Technology Zurich 


\title{
Expert Views on Sustainability and Technology Implementation'
}

\author{
David Laws", Roland W. Scholz", Hideaki Shiroyama", Lawrence Susskind", \\ Tatsuro Suzuki*** Olaf Weber** \\ In co-operation with \\ Jonna Anderson", Ginette Chapman", Marcus Fenchel", Koji Isozumi"*", \\ Emily Rubenstein*, Jaisel Vadgama*, Masaru Yarime***
}

\section{Contents}

Contents

Abstract

Goals and Motives 3

Design and Procedure for the Interviews ......................................................................................................................... 4

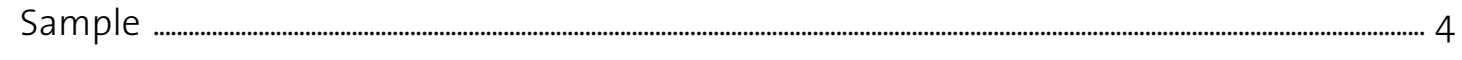

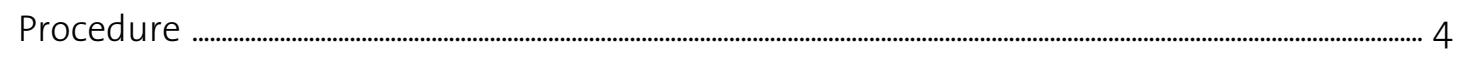

Questionnaire ......................................................................................................................................

Data analysis .................................................................................................................................................................................... 6

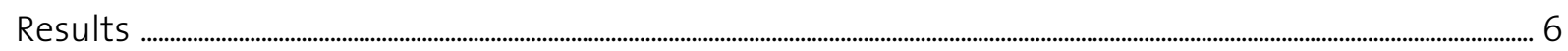

Where do the experts come from? ........................................................................................................... 6

What is the reference project? ....................................................................................................................................................

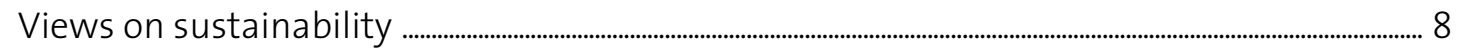

Views on implementation .................................................................................................................................................... 10

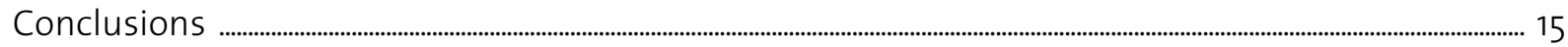

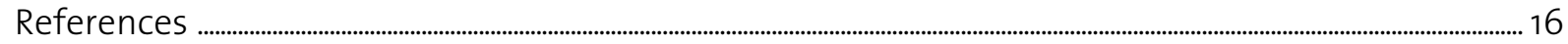

This study was organized by the Breakthroughs in Sustainable Technology and Action, and supported by funding from the Alliance for Global Sustainability.

* Environmental Technology and Public Policy Program, Department of Urban Studies and Planning, Massachusetts Institute of Technology

** Chair of Natural and Social Science Interface (ETH-UNS), Department of Environmental Sciences, ETH Zurich

${ }^{* * *}$ Faculty of Law, University of Tokyo

${ }^{* * * *}$ Central Research Institute of Electric Power Industry, Japan 


\section{Abstract}

Twenty-one senior faculty members and researchers were interviewed about their conception of sustainability and their understanding of implementation in projects linked to the Alliance of Global Sustainability, a joint project of MIT (Boston), ETH (Zurich and Lausanne), UT (Tokyo), and Chalmers (Gothenburg).

We identified five complementary views on sustainability, i.e. i) science is sustainable per se, ii) sustainability is an ethical relationship with the past and future, iii) sustainability is the maintenance of a system within functional limits, iv) eco-efficiency, v) sustainability is a form of ongoing inquiry. In total, the conception of ethical relationship was the most dominant conception whereas science per se and eco-efficiency were less used. Researchers with a natural science background raised more aspects of sustainability and more emphasized limit management Ecoefficiency is important for professors with a social science but not for those with a natural science background.

Most of the researchers regarded implementation as the process whereby their work comes into contact with social groups and processes and where concerns about taking action and social technology change became prominent. The interviewed researchers considered successful implementation to be linked to value change, efficient information policy, institutional action but not regulations and supposed technology implementation to creates new allocations, i.e. winners and losers.

The relationship between knowledge and action is considered central in views on implementation. Three different conceptions and habits could be identified with respect to this relationship, i.e. a) action: I act to change the world; b) interaction, I exchange information with my environment through my actions, c) transaction or mutual learning. I change as a result of my effort to bring about change in the word.

The concept of sustainability has a surprisingly long tradition and is a child of the $17^{\text {th }}$ century crises in forest overuse due to shipping construction and mining. The concept goes back to the Saxonian Oberberghauptmann von Carlowitz, a "principal captain" in the Saxonian silver mining business In his volume Sylviculturum Oeconomica. Die Naturmäßige Anweisung zur Wilden Baum-Zucht (Leipzig 1713, [engl. Nature based guidelines for breeding of the wild tree.]), he was concerned about "wie eine sothane Conservation und Anbau des Holtzes anzustellen, daß es eine continuirliche, beständige und nachhaltige Nutzung gebe." [ engl., "how to accomplish conservation and growing of wood that a continuous, steady, and sustainable can become possible."] In this quote the technical term [engl. sustainable was firstly defined (DIE ZEIT, Nov. $25^{\text {th }}$, 1999, No. 48, p. 98). 


\section{Goals and Motives}

Sustainability has always been an elusive term. As we begin to look at how to sustainability should be implemented in action, it become even more so. The variety of theoretical and practical backgrounds that the groups and individuals who work on sustainability bring to bear on the problem come directly into play and affect our ability to understand each other. These differences can be a source of richness, but they also mean it is difficult to keep track of what we mean when we ask whether an action or technology is sustainable. As our use of the term shifts and we interact with others who use sustainability in different ways, understanding becomes a persistent problem. This is especially true in a program like the Alliance for Global Sustainability (AGS), which frames our common project and interaction. AGS is an enterprise based on the premise that exchange across the diverse backgrounds of engineers, natural scientists, and social scientists is not only possible, but can contribute to a richer and more practical understanding of how the problem of sustainability should be understood and how sustainable technology development should be organized.

Our goal in this study was to create a snapshot of how we, as a group of experts who come together under the banner of AGS understand the meaning of sustainability and good implementation in sustainable technology development. We asked a group of researchers at the annual AGS meeting in Lausanne in January, 2001 to participate in an interview study that might shed some light on the theory of practice that is developing within AGS. We asked participants to articulate their insights based on their experience in a project that reflects the boundaries, potential, and difficulties of work on sustainable technology development.

The experts who participated in this study are researchers, coordinators, or sponsors at one of the three AGS universities, or an affiliated university. All were involved in a project or study related to technology that involved or raised questions about implementation.

The concept of an "expert" is itself a difficult one that has been defined differently when it has become the focus of explicit study in fields like sociology and psychology. In sociology, the focus has been placed on the social role of the expert and the professionalization of domains of activity (Abbott, 1988). On the psychological side, the focus on has been on ways of thinking and knowing, cognition, and the way knowledge is organized (Dreyfus \& Dreyfus, 1986; Chi, Glaser, \& Farr, 1988). There is no common definition besides an expert is an individual who has expertise and can report on it. In our understanding expertise must involve experiential and context-bound knowledge that differentiates it both from sophistication and from a specialist (Scholz, 1987). An expert functions in an interaction or a discourse and combines competence in this interaction with experience and insight into what, why, and how-to do something (Mieg, 2001). In this study we emphasize the experiential roots of expertise and experts' intuitive understanding of a problem field.

We engaged experts as "theorists-of-practice" and asked the participants to talk about a project (i.e. a particular interaction or discourse) in which they used sustainability to try to get access to their intuitive understanding. From a sociological perspective, one of the functions of an expert is to bind uncertainty. This study can be understood in these terms, as a step to a clearer and more robust understanding of the state of the art in our common project. 


\section{Design and Procedure for the Interviews}

\section{Sample}

Our study is based on interviews with 21 senior faculty and researchers who had substantial experience with an AGS project. This sample was not stratified, but was designed in order to achieve distribution with respect to academic affiliation (ETH, UT, MIT), professional background, and type of project and technology. It included several project coordinators and two representatives of Chalmers Technical University of Gothenborg.

\section{Procedure}

The interviews were performed by teams of graduate students from ETH, MIT, and UT. In a few instances, interviews were performed by a single student. Each interview ran between a half an hour and one hour. After each interview, the team discussed the session and wrote a summary together. The interviewers described the study to participants as a pilot study on implementation strategies for sustainable technology development. Our analysis summarizes across the interviews. No statements can (or should) be personally attributable to individual experts. The authors instructed the interviewers in the protocols and procedures and held a pilot session in which each interviewer conducted a trial interview and reviewed the experience with one of the authors (who all are members of the AGS research team).

\section{Questionnaire}

The first cluster of questions we analyze addresses views on sustainability. We compiled an initial list of five distinct interpretations of sustainability. The concept of sustainability as eco-efficiency was identified in the study and added to the list for the analysis of the interviews ${ }^{2}$.

- Science is sustainable per se. This perspective holds that the best contribution scientists can make to a sustainable future is to conduct good research. Generating knowledge and upholding standards of open exchange and critical examination of experience provide the insight and model the kind of social interaction that will move us in the direction of sustainability.

- Sustainability is an ethical relationship with the past and future. This refers to perspectives that evaluate actions from the perspective of their significance for and impacts on other persons. The primary example is intergenerational equity as expressed in the Brundtland Commission's definition of sustainable development as that which serves the needs of the present generation without compromising the ability of future generations to meet their needs. The same sort of consideration of ethical relationships can function intra-generationally. Participants in the debate over the responsibilities of the North and the South with respect to issues like reducing green house gas emissions

A sixth conception labeled as conservation (sustainable development means that everything remains as it is was not further presented to some ambiguities in the rating and confounding with other notions, e.g. "maintenance of a system in its limits." 
commonly draw on this kind perspective to evaluate proposals. In the U.S., environmental justice has drawn on a similar kind of perspective-taking to evaluate the distribution of the historical burdens of environmental contamination.

- Sustainability is the maintenance of a system within functional limits. This perspective draws on systems dynamics and treats sustainability as the ability to master the potential for change in a system by identifying functional limits and taking steps to maintain the system within those limits. Development is managed by keeping action within a "funnel" of possibility in which the inner domain provides a flexible set of options that can be treated as sustainable as long as they don't violate the boundaries of the funnel.

- Eco-efficiency. The most common interpretation of this perspective considers sustainability in terms of the relationship between economic and environmental benefits. Whereas this relationship is often treated as a strict tradeoff, eco-efficiency posits that environmental benefits can be enhanced at the same time as economic performance.

- Sustainability is a form of ongoing inquiry. This perspective treats sustainability as a provisional goal. Action is important not just for furthering the goal, but also for informing the (re)interpretation of the goal. Sustainable development is a process of learning in which action is shaped by goals and goals are revised in light of experience. The commitment to sustainability is understood as a commitment to this process, rather than to a fixed conception of the goal. Transdisciplinarity (see Gibbons et al., 1994; Häberli et al., 2001) and consensus building (Susskind, McKearnan, \& ThomasLarmer, 1999) are developed forms of inquiry along these lines that provide methods for organizing interaction and integrating knowledge and values.

We consider these views to be complementary (rather than disjunctive) facets of the concept field of sustainability. Any person can hold more than one of these perspectives without engaging in a contradiction. In this study, we were interested in discerning which conceptions of sustainability were reflected in experts' thinking about current AGS projects.

The second cluster of questions analyzed concern perspectives on implementation. We asked the interviewers to look for statements that provide insight into the experts' views on what implementation means in the context of sustainability. We did not provide the interviewers with a template of a priori perspectives for this cluster.

Like expertise and sustainability, implementation is used in different ways with different meanings. The classical notion of implementation draws on a model of applied science. Knowledge derived from theory and disciplinary research is applied to improve or perfect problemsolving in the world. Implementation refers to the process of applying the insights derived from research and theory. Policy often serves as a middle-man in this process, translating insights into programs. Thus implementation has attracted substantial attention in public policy and also in organizational development. The main effect of this attention has been to turn the classical relationship between knowledge and action "on its head." (Argyris \& Schön, 1996; Pressman \& Wildavsky, 1984; Rein \& Rabinovitz, 1980; Rein, 1983). Implementation research has em- 
phasized how efforts to take action reveal the contradictory imperatives that underpin commitments, surface the complexity and dynamic conservatism of social and physical systems, and engage the intuitive, domain specific knowledge of the "street-level" practitioners who work to produce change on a daily basis (see Lipsky, 1980). Our approach to getting access to experts' views on implementation parallels our approach to capturing views on sustainability. We try to get access to the experts' intuitive understanding of implementation in the specific domain of sustainable technology development.

For each interview, we asked the interviewers to identify core statements that represented the respondent's view on each of the three clusters. Core statements are salient comments that highlight certain facets of the experts' perspective and relate to our framework.

\section{Data analysis}

We based our data analysis on the written protocols. Core statements were explicitly documented in the summaries of the interviews. Though the number of interviewees is too small for statistical analysis, we present some tables and frequencies that we believe convey the gist of the qualitative data from the interviews. Due to the exploratory character of the pilot study, we did not formulate any explicit hypotheses. We expected that the dominant characterizations would be closely associated with compatible themes in the technical backgrounds of the experts. Thus we will also present some frequency statistics that address these expectations.

A post hoc analysis suggests that some of the variation may be attributable to differences in the approaches that the five interview teams took. Because we could not detect any systematic effect of the variation in the backgrounds of the interviewers we do not report any analysis of these issues.

\section{Results}

\section{Where do the experts come from?}

Most of the experts who were asked agreed to participate in the study. This meant finding time within the busy schedule of the conference. Only one expert who was invited declined to participate--because he considered himself a basic researcher. To him this meant that others have the responsibility for thinking about implementation and sustainability. Twenty-one experts were interviewed. Table 1 presents the frequency distribution with respect to national affiliation (i.e. schools) and professional background. As there is no crisp differentiation between natural science and engineering, we differentiated with respect to graduate diploma, as this provides the primary 'career socialization.' The category 'others' encompasses participants whose primary professional identification is in the social sciences, urban planning, or architecture. 
Table 1 . Frequencies of nationality and professional background for the 21 experts

\begin{tabular}{r|cccc|c}
\hline \multicolumn{7}{c}{ Observed Frequency Table } \\
\hline & Switzerland & USA & Japan & Sweden & Totals \\
\hline Natural Sciences & 3 & 1 & 1 & 0 & 5 \\
Engineering Sciences & 4 & 2 & 4 & 2 & 12 \\
Others & 2 & 1 & 1 & 0 & 4 \\
\hline Totals & 9 & 4 & 6 & 2 & 21 \\
\hline
\end{tabular}

The experts were asked to describe their role in the AGS project they had chosen to focus on for the interview: 12 described themselves as primary investigators or coordinators, 5 said that they were researchers, 3 primarily supervised students or had another supervisory role.

\section{What is the reference project?}

Each interview began with the selection of a reference project. This was a project that was underway or recently completed, in which sustainability played a substantial role in setting the research focus. Preference was given to projects that were organized as part of AGS. We have classified these projects according to their origins, geographic reach, and focus. The origins are grouped into five categories. Each project had a primary reason for organizing; some had secondary reasons.

Table 2. Project origins according to experts' accounts.

\begin{tabular}{l|cc}
\hline Origin & $\begin{array}{c}\text { Experts citing this } \\
\text { as primary impetus }\end{array}$ & $\begin{array}{c}\text { Experts citing this } \\
\text { as a secondary } \\
\text { impetus }\end{array}$ \\
\hline $\begin{array}{l}\text { Idea arose in discussion with other researchers or another } \\
\text { researcher invited the expert to join }\end{array}$ & 6 & 1 \\
\hline $\begin{array}{l}\text { Independent academic interest in the problem (often as a } \\
\text { case study) }\end{array}$ & 5 & 2 \\
\hline $\begin{array}{l}\text { Personal interest in the problem or contact in a specific } \\
\text { country }\end{array}$ & 3 & 4 \\
\hline Social / ethical concerns & 3 & 0 \\
\hline Researcher was approached by client & 4 & 2 \\
\hline
\end{tabular}

We grouped projects into four geographic categories, which are mutually exclusive:

- 2 domestic projects focused only within the expert's country

- 2 international projects focused on other developed countries

- 11 international projects focused on developing countries

- 6 projects that apply equally to domestic and international contexts (for example, global climate modeling). 
Finally, we grouped projects according to the substantive focus of the research. The research foci are not categorized by subject areas (e.g. hydrology) or by professional affiliation (e.g. mechanical engineering; chemistry) because these categories did not capture the subtle distinctions that the researchers who participated in the study used to describe their projects, relate them to sustainability, and situate them in their career paths. Instead, we relied on distinctions that reflect the terms that experts used. Sustainable information technology implementation can be understood as: a) a physical process of data acquisition and transmission or the social process of using the technology in a cultural context; b) the type of knowledge or information that can be stored and presented; c) in terms of the relationship between the development of knowledge, organizations, and institutions; d) as a physical product with a specific history and design horizon; e) in terms of the infrastructure demands it creates; and, f) in terms of the dynamic relationship between materials and product design.

Table 3. Primary and secondary focus of the reference project.

\begin{tabular}{l|cc}
\hline Focus & $\begin{array}{c}\text { Experts citing this as primary } \\
\text { focus }\end{array}$ & $\begin{array}{c}\text { Experts citing this as secondary } \\
\text { focus }\end{array}$ \\
\hline Processes [physical and social] & 16 & 4 \\
\hline Information / knowledge & 10 & 3 \\
\hline Institutions / organizations & 6 & 4 \\
\hline Physical product / machines & 6 & 2 \\
\hline Infrastructure & 4 & 4 \\
\hline Materials & 1 & 0 \\
\hline Other & 2 & 4 \\
\hline
\end{tabular}

The forty-five primary and twenty-one foci that are reported reflect the complex terms in which researchers described their projects. The interviews suggest that sustainable technology implementation demands new types of distinctions that go beyond the traditional categories of academic disciplines.

\section{Views on sustainability}

We first report on the frequency with which the five conceptions of sustainability were used in the personal interviews. We rated each interview on a scale of o to 3 with respect to each of the five views on sustainability. Each rating was done by two authors. A rating of 'o' designates that this facet of sustainability was not observable in the context of the interview. A rating of ' 1 ' is given for minor indications of the facet, a ' 2 ' for medium, and a ' 3 ' for strong. ' 1 ,' '2,' and ' 3 ' were all considered observable. Table 4 summarizes the ratings. 
The most prominent findings are highlighted in the shaded cells. The following interpretations are suggested by the data for the comparison between the aspects

- Ethical relationship was the most prominent view across the groups. 15 out of 21 participants conveyed that they linked their project to this aspect of sustainability.

- Science per se was observed less frequently than any of the other aspects.

- Eco-efficiency also received a low score.

Some interesting observations emerge from a comparison between the groups, natural scientists ( $N$ ), engineers ( $E)$, and other $(O)$.

- The interviews with the engineers raised more aspects of sustainability across the board.

- In particular, engineers emphasized conservation and limit management.

- Eco-efficiency is not important to the natural scientists. It seems to be more prominent from a social science perspective.

- Ongoing inquiry got a medium score in all groups.

Table 4. Number of "observable" and "non-observable" aspects and mean scores for the groups [natural scientists $(N)$, engineers $(E)$, and other $(O)$ ] on the sustainability aspects.

\begin{tabular}{l|cccc|cccc|cccc}
\hline & \multicolumn{4}{|c|}{ “observable" } & \multicolumn{5}{c|}{ “Non-observable" } & \multicolumn{5}{c}{ Mean score } \\
\hline $\begin{array}{l}\text { Sustainability } \\
\text { aspect }\end{array}$ & $\mathrm{N}$ & $\mathrm{E}$ & $\mathrm{O}$ & All & $\mathrm{N}$ & $\mathrm{E}$ & $\mathrm{O}$ & All & $\mathrm{N}$ & $\mathrm{E}$ & $\mathrm{O}$ & All \\
\hline $\begin{array}{l}\text { Science per se } \\
1\end{array}$ & 2 & 0 & 3 & 4 & 10 & 4 & 18 & 0.2 & 0.3 & 0.0 & 0.2 \\
\hline $\begin{array}{l}\text { Ethical } \\
\text { relationship }\end{array}$ & 2 & 10 & 3 & 15 & 3 & 2 & 1 & 6 & 1.2 & 1.8 & 1.0 & 1.5 \\
\hline $\begin{array}{l}\text { Ecoefficiency } \\
\text { Limit }\end{array}$ & 0 & 4 & 2 & 6 & 5 & 8 & 2 & 15 & 0.0 & 0.6 & 1.0 & 0.5 \\
\hline $\begin{array}{l}\text { Onangoing } \\
\text { inquiry }\end{array}$ & 1 & 8 & 0 & 9 & 4 & 4 & 4 & 12 & 0.4 & 1.3 & 0.0 & 0.8 \\
\hline All aspects & 6 & 30 & 7 & 41 & 19 & 30 & 13 & 62 & 0.42 & 0.94 & 0.57 & \\
\hline
\end{tabular}

For exploratory purposes we also conducted contingency, correlation, and factor analyses. The sustainability aspects do not seem to be highly correlated, however there seems to be some contingency between science per se and limit management. The other is that ethical relationship and ongoing inquiry are rarely found together. 
Core statements

The core statements below give an idea of what is behind the classifications and frequencies reported in Table 4.

Ethical relationship

"... Sustainability ... is a stakeholder approach to the future generation ..."

"... We have to have future generations to have freedom ..."

"... Sustainability is to provide transportation services efficiently and equally ..."

"... We need to awaken other values ... hate, love, passion ..."

Eco-efficiency

"... sustainability is a balancing of costs ..."

Limit management

"... using with .. don't impact the whole water cycle ..."

"... preventing positive feedback loops..."

Ongoing inquiry

"...finesse in ... information and other means ... .. human needs identification"

\section{Views on implementation}

\section{A consensus on the importance of impacts}

A prominent characteristic of the survey is the concern the interviewees shared about the nature of the impacts their research will have. This led, in turn, to a concern with implementation. All the researchers had thought about implementation and how it related to their project. They saw themselves as working on problems that had implications for action and hoped their efforts would modify impacts of affect the behavior or impacts of some group or class. They could all identify, for instance, who might or should be affected by their research. This concern is evident in core statements like:

"... Our final goal is really to have an impact. ..."

"... The worst thing that could happen is that we don't have an impact. ..."

“...Part of our task is to develop feasible strategic options. . . we have to keep in mind what it is that can be implemented...."

"... We share the view that in thirty years the entire infrastructure could change...."

An interesting question was raised, but not answered, by the interviews. Does the substantive focus on sustainability generate the observed tie between research and implementation? In other words, 'Does research on sustainability inherently raise concerns about implementation?' Only a few of the researchers in the sample had not acted on their concerns with impacts by taking at least some steps to address implementation. 
Understanding implementation

This consensus carried over to the broad terms in which the researchers described implementation. They saw implementation as the process whereby their work as researchers comes into contact with social groups and processes and where concerns about taking action and social and technological change become prominent. This tie extended the relationship between research and values, and institutions that we observed in the terms the participants used to define sustainability. The participants also gave a great deal of attention to barriers to change. The most prominent categories in which the researchers discussed the relationship between their work and social change are reviewed below.

Value change is tied to implementation

Concern with implementation introduces values and "life attitudes." Some members of the sample included scientific commitments in this class of concerns. The central idea is that change - in technologies, in patterns of use, or in policies - implies or requires change in values. Some discussed this relationship in terms of consumer preferences that shape the marketability of "green" products. Others treated values in broader terms as concerns that provide the foundation for moral commitment and political action, such as a concern about social equity. The former were generally treated as barriers or brakes on implementation - change is difficult because the values that guide individual choice are uninformed or inconsistent. These preferences can make it difficult to sell a higher mileage car, for instance. Those who adopted the latter approach tended to see values as a source of commitment that contributes to change, rather than as a barrier. They cited the "need to awaken other values relating to sustainability" for example.

\section{Information influences technology implementation}

The mismatch between the demands of sustainability and social values was often discussed in terms of a need for education. The shortage of accurate and accepted information on environmental problems was viewed by many as a brake that inhibits the development of values that are consistent with sustainability. As some members pointed out, however, clearer and more comprehensive information can also trigger controversy. This did not dampen their enthusiasm for more information and broader public understanding, but did underscore the irony that can attend the development and dissemination of new information.

\section{Institutions shape sustainable action}

Insstitutions were commonly referenced in discussions of implementation (see Table 2). The dominant accounts discussed the barriers that institutions raise and the way they distort efforts to take action and promote change. Subsidies, for instance, were described as an institutional device that distorts information and incentives. Regulations, in turn, were characterized as rigid requirements that often fail to take account of, or leave room for, local contextual knowledge. Even where the need for regulation was acknowledged, some interviewees were quick to point out the importance of paving the way for new regulatory initiatives with a round 
of deregulation. The rigidity of bureaucracies and rules, and their inherent resistance to change, were raised frequently in the interviews.

Elections (and the electoral politics that accompany them) were described as a problematic institution because of the way they foreshorten time horizons, distort the framing of problems, and dilute attention.

The distribution of costs and benefits shapes sustainable action

New technologies and biophysical changes like climate change create winners as well as losers. The impacts these changing distributions can have on implementation were a prominent theme in the researchers' accounts. This awareness did not lead to clear cut guidelines for action. Interventions on either side can distort or slow change. Winners may promote a favored option or block intervention when the change is beneficial to them. Losers seeking to protect their interests often see the only avenue open is opposition to change.

\section{Sustainable action is transdisciplinary and cross-cultural}

Finally, researchers regarded the character of the problems they work on as important. They saw the problems they are working on as transdisciplinary and often cross-cultural. Both characteristics put distinctive demands on practice, particularly on the need for communication, that affected implementation.

\section{Knowledge and action in technology implementation}

The relationship between knowledge and action is central in views on implementation. It shapes the terms in which knowledge generation is understood and organized and the researchers' professional understanding. In this section, we extend the report in the preceding sections by tracing and constructing patterns in the comments of interviewees that have pragmatic significance for interpreting the relationship between knowledge and action. Unlike the preceding sections, this interpretation is not meant solely as an attempt to classify the interviews. Instead we try to render from the comments an interpretation that may provide insight into the increasing social complexity that attends technology implementation around problems like sustainable development and the emerging character of sustainability as a problem field. Such an interpretaton can help us understand the theory-practice interaction that is central to implementation and reflect on the relationship between knowledge and action in sustainability projects. We summarize our interpretation in three stylized "theories of action" and present for each core statements from the interviews that are consistent with these interpretations. These theories suggest the complexity that characterizes thinking about implementation within the AGS and may also offer some more general insights into the development of professional understanding as fields of engineering and science become more tightly coupled to social problems like sustainability.

In naming these patterns we maintain consistency with terminology for consistency while extending these terms in light of the insights provided in the interviews. (See Dewey \& Bentley, 1960) 
Action. I act to change the world.

In this view, the researcher is a problem solver who looks at the larger context and asks, "How can I make a difference?" New knowledge and new technologies are important because they can trigger change. One role of research is to inform people of the urgency of problems and possible actions. Publishing is a prominent and effective way to accomplish this because it disseminates results widely and is durable over time. Education may also help to overcome the lack of public understanding, awareness, and commitment that are the key barriers to implementing the results of research projects. New technologies are important because they change structures and open new pathways of action.

It may also be important to find actors with "leverage" to get thing across and push necessary changes. Implementation follows the development of new understanding or new technologies and is a problem of instigating people to adopt new forms of behavior.

Illustrative core statements.

- "I'm confident, if there is a need and, more importantly, a market, the technology will be developed."

- "Society is either disinterested or uninformed about environmental issues. Media can teach people on a worldwide and local basis - both are important."

- "Law and policy should be changed to provide appropriate incentives to change the behavior of users of transportation."

- "In order to improve [the] situation, the level of education is important - parents are not teaching children how to behave."

- "If implementation means dissemination of the results, all results were implemented."

- "A challenge is "having enough confidence in the science part of the equation to say to the politicians who don't like to pass regulation ... that the necessity is there."

- "People's value systems are strongly related to sustainability. People have to change their lifestyles."

- "Changes have to be "institutionalized" to have long-lasting influence. This requires "outreach and education" of the public. Government must have the resources to educate the public."

Interaction. I exchange information with my environment through my actions.

Here the researcher who seeks change tries to gather information from other people and, subsequently, to promote change by providing the public with new information about impacts and options. A prominent characteristic of this view is the importance of preserving a liberal sphere of autonomy. Consumers, for example, should retain the right to make choices. The role of research is to ensure that these choices are informed and that new options are available at a reasonable cost. Outreach is important to understand consumer and political preferences so that options can respond to what people want. Marketing is important to highlight new op- 
tions. Education supports marketing by providing information to inform preferences. Implementation should be anticipated in the early stages of development by gathering information on preferences and practices.

Illustrative core statements

- “... Any new measures that are taken, we have to explain them, so that [the] public accepts them...."

- “... We should form alliance with manufacturers, city government, and suppliers. Suppliers need to put fuel in place. Manufacturers need to advertise [their] product. ..."

- “... We are working a lot with stakeholders. You have think about consumer access. A good technical product does not guarantee customer acceptance of diffusion. ..."

- "... Will the values of society be such that environmentally friendly products will be accepted?..."

- “... Information has to be available so that "people don't feel left out. ..."

Transaction or mutual learning. I change as a result of my effort to bring about change in the world.

The effort to take action changes the actor who seeks to promote change. Boundaries between the actor and her environment are difficult to sustain in implementation. Stakeholder involvement, for instance, becomes a process in which the researcher's understanding of the problem and of options for action develops. The importance of local knowledge (as opposed to, say, local preferences) is acknowledged. Education becomes learning. Researchers describe their surprise at new insights and options that develop through working together on a problem. Relationships among research partners (in interdisciplinary projects) and between researchers and users are discussed in terms of trust and understanding. The development of these relationships is essential for effective implementation and must start from the beginning of a program. Implementation cannot be separated from the development of the project.

Illustrative core statements

- “...Developing a relationship is very important for success. It takes a long time. ..."

- “... They (the local partner) are a good partner and help us a lot. Without them we couldn't develop these processes...."

- “... Good quality management will be a management that cares for consumers and ecoefficiency...."

- “... The best way to implement this project is to build an atmosphere of mutual respect with partners. This can take years...."

- "... If you integrate quality as you conceive a product then quality will in fact reduce the cost. ..." 


\section{Conclusions}

The interviews in this study reveal that status of sustainability is a complex problem field. Researchers who work in this field see sustainability in complex terms that combine a conventional understanding of research with a concern for ethical relationships and the need to take action in the world. The evidence we have presented is consistent with the interpretation that the field is in a process of historical development, though it is not sufficient to conclude that this process is going on or provide clear indication of the direction of the developmental process.

The evidence from the interviews suggests a number of findings that may provide grist for further reflection.

- The ethical standard of sustainability is the most common and most frequently presented.

- Ongoing inquiry is more visible than expected. Experience in sustainability projects appears to highlight the importance of the process.

- Engineers are close to the process and operations. This orients to concerns with management and correction or repair.

- The negative correlation between ethical interpretation and ongoing inquiry suggests that researchers may start with normative commitment and move on to process, but this is clearly beyond the data.

- Experience with sustainability projects promotes and reinforces concerns about implementation.

- Concern with implementation appears to promote consideration of the relationship between knowledge and action, though no core consensus has developed on this relationship.

In our interviews with researchers we found committed transdisciplinarians. Many think about the relationship between different domains of knowledge in their work and draw on both ethical and epistemological considerations to explain their efforts. They know implementation is important and had given it thoughtful consideration prior to the interviews. These concerns provide substantial common ground, even if disagreements persist about the meaning and implications of these terms. We conclude the study hopeful about the potential these "meaningful disagreements" provide for further research, collaboration, and efforts to take action in the world. 


\section{References}

Abbott, A. (1988). The system of professions: An essay on the division of expert labor. Chicago: University of Chicago Press.

Argyris, C., \& Schön, D. A. (1996). Organizational learning II: Theory, method, and practice. Reading, MA: Addison-Wesley.

Chi, M. T. H., Glaser, R., \& Farr, M. J. (Eds.). (1988). The nature of expertise. Hillsdale, NJ: Erlbaum.

Dewey, J., \& Bentley, A. (1960). Knowing and the known. Boston: Beacon Press.

Dreyfus, H. L., \& Dreyfus, S. E. (1986). Mind over machine. Oxford, England: Blackwell.

Gibbons, M., Limoges, C., Nowotny, H., Schwartzmann, S., Scott, P., \& Trow, M. (1994). The new production of knowledge: The dynamics of science and research in contemporary societies. London: Sage.

Häberli, R., Bill, A., Grossenbacher-Mansuy, W., Thompson Klein, J., Scholz, R. W., \& Welti, M. (2001). Synthesis. In J. Thompson Klein \& W. Grossenbacher-Mansuy \& R. Häberli \& A. Bill \& R. W. Scholz \& M. Welti (Eds.), Transdiciplinarity: Joint problem solving among science, technology, and society. An effective way for managing complexity (pp. 6-22). Basel: Birkhäuser.

Lipsky, M. (1980). Street level bureaucracy. New York: Russel Sage.

Mieg, H. A. (2001). The social psychology of expertise: Case studies in research, professional domains, and expert roles. Mahwah, NJ: Erlbaum.

Pressman, J. L., \& Wildavsky, A. (1984). Implementation: How great expectations in Washington are dashed in Oakland; or, why it's amazing that federal programs work at all, this being a saga of the economic development administration as told by two sympathetic observers who seek to build morals on a foundation of ruined hopes (3rd ed.). Berkeley, CA: University of California Press.

Rein, M. (1983). From policy to practice. Armonk, NY: M. E. Sharpe.

Rein, M., \& Rabinovitz, F. (1980). Implementation: A theoretical perspective. In W. D. Burnham, \& M. W. Weinberg (Eds.), American politics and public policy (pp. 307-335). Cambridge, MA: MIT Press.

Scholz, R. W. (1987). Cognitive strategies in stochastic thinking. Dordrecht, The Netherlands: Reidel.

Susskind, L., McKearnan, S., \& Thomas-Larmer, J. (Eds.). (1999). The consensus building handbook: A comprehensive guide to reaching agreement. Thousand Oaks, CA: Sage. 


\section{ETH-UNS Working Papers}

UNS-Working Paper 1 (Out of Print)

Scholz, R.W. (1994). Muss man den Formalismus beherrschen, um die Formalisten zu schlagen? Zürich: ETH Zürich, Umweltnatur- und Umweltsozialwissenschaften.

(Published as: Scholz, R.W. (1998). Umweltforschung zwischen Formalwissenschaft und Verständnis: Muss man den Formalismus beherrschen um die Formalisten zu schlagen? [Environmental research between formal science and comprehension: is command of the formalism necessary for beating the formalists?] In A. Daschkeit \& W Schröder (Eds.), Umweltforschung quergedacht: Perspektiven integrativer Umweltforschung und lehre [Environmental research thought laterally: perspectives on integrating environmental research and teaching] (pp. 309-328). Berlin: Springer.)

- UNS-Working Paper 2 (Out of Print)

UNS (1994). Lehrstuhlbeschreibung Umweltnaturund Umweltsozialwissenschaften (UNS). Fallstudie, Forschung und Berufspraxis. Zürich: ETH Zürich, Umweltnatur- und Umweltsozialwissenschaften.
- UNS-Working Paper 3

Mieg, H.A. (1994). Die Expertenrolle. Zürich: ETH Zürich, Umweltnatur- und Umweltsozialwissenschaften.

- UNS-Working Paper 4

Heitzer, A. \& Scholz, R.W. (1994). Monitoring and evaluating the efficacy of bioremediation - a conceptual framework. Zürich: ETH Zürich, Umweltnatur- und Umweltsozialwissenschaften. 
UNS-Working Paper 5 (Out of Print)

Scholz, R.W., Weber, O. \& Michalik, G. (1995). Ökologische Risiken im Firmenkreditgeschäft. Zürich ETH-Zürich, Umweltnatur- und Umweltsozialwissenschaften.

(Published as: Scholz, R.W., Weber, O., and Michalik, G. (1995). Ökologische Risiken im Firmenkreditgeschäft. [Ecological risks in loans to enterprises] In Overlack-Kosel, D Scholz, R.W Erichsen, S Schmitz, K. W. and Urban, G. (Eds.), Kreditrisiken aus Umweltrisiken [Loan risks due to environmental risks (pp. 1-49). Bonn: Economica.)

UNS-Working Paper 6 (Out of Print)

Scholz, R.W., Heitzer, A., May, T., Nothbaum, N. Stünzi, J. \& Tietje, O. (1995). Datenqualität und Risikoanalysen - Das Risikohandlungsmodell zur Altlastenbearbeitung. Zürich: ETH Zürich, Umwelt natur- und Umweltsozialwissenschaften.

(Published as: Scholz, R.W., Heitzer, A., May, T. W., Nothbaum, N. Stünzi, J and Tietje O (1996). Datenqualität und Risikoanalysen: Das Risikohandlungsmodell zur Altlastenbearbeitung. [Data quality and risk analyses. The Risk Action Model of soil remediation] In S. Schulte-Hostede, R. Freitag, A. Kettrup, and W. Fresenius (Eds.), Altlasten-Bewertung: Datenanalyse und Gefahrenbewertung [Evaluation of soil remediation cases: analysis of data and evaluation of risks] (pp. 1-29). Landsberg: Ecomed.)

UNS-Working Paper 7 (Out of Print)

Scholz, R.W., Mieg, A.H. \& Weber, O. (1995). Mastering the complexity of environmental problem solving by case study approach. Zürich: ETH Zürich, Umweltnatur- und Umweltsozialwissenschaften.

(Published as: Scholz, R.W., Mieg, H.A., and Weber, O. (1997). Mastering the complexity of environmental problem solving with the case study approach. Psychologische Beiträge, [Contributions to Psychology] 39, 169-186.)

- UNS-Working Paper 8 (Out of Print)

Tietje, O. \& Scholz, R.W. (1995). Wahrscheinlichkeitskonzepte und Umweltsysteme. Zürich: ETH Zürich, Umweltnatur- und Umweltsozialwissenschaften.

(Published as: Tietje, O. and Scholz, R.W. (1996) Wahrscheinlichkeitskonzepte und Umweltsysteme. [Concepts of probability and environmental systems] In A. Gheorghe \& H. Seiler (Eds.), Was is Wahrscheinlichkeit? Die Bedeutung der Wahrscheinlichkeit beim Umgang mit technischen Risiken [What is probability? The meaning of prob ability in the case of technical risks] (pp. 31-49). ability in the
Zürich: vdf.)

UNS-Working Paper 9 (Out of Print)

Scholz, R.W. (1995). Grenzwert und Risiko: Probleme der Wahrnehmung und des Handelns. Zürich: ETH Zürich, Umweltnatur- und Umweltsozialwissenschaften.

(Published as: Scholz, R.W. (1996). Grenzwerte und Risiko: Probleme der Wahrnehmung und des Handelns. [Standards and risks: Problems of cognition and of action] In A. Grohmann \& G. Reinicke (Eds.), Transparenz und Akzeptanz von Grenzwerten am Beispiel des Trinkwassers [Transparency in the setting of standards and their acceptance in the cas of drinking water] (pp. 5-19). Berlin: Erich Schmidt Verlag.)

- UNS-Working Paper 10 (Out of Print)

Weber, O. (1995). Vom kognitiven Ungetüm bis zur Unverständlichkeit: Zwei Beispiele für Schwierigkeiten im Umgang mit Grenzwerten. Zürich: ETH Zürich, Umweltnatur- und Umweltsozialwissenschaften.

(Published as: Weber, O. (1996). Vom kognitiven Ungetüm bis zur Unverständlichkeit: zwei Beispiele für Schwierigkeiten im Umgang mit Grenzwerten. [From cognitive monsters to incomprehensibility: two examples of difficulties in managing standards] In Umweltbundesamt (Ed.), Transparenz und Akzeptanz von Grenzwerten am Beispiel des Trinkwassers. Berichtsband zur Tagung vom 10. und 11 Oktober 1995 (mit Ergänzungen), [Transparency in and acceptance of standards. The case of drinking water] (pp. 133-150). Berlin: Erich Schmidt Verlag.)
- UNS-Working Paper 11

Oberle, B.M., Meyer, S. B. \& Gessler, R.D. (1995) Übungsfälle 1994: Ökologie als Bestandteil von Unternehmens- strategien am Beispiel der Swissair Zürich: ETH Zürich, Umweltnatur- und Umweltsozialwissenschaften.

UNS-Working Paper 12 (Out of Print)

Mieg, H.A. (1996). Managing the Interfaces between Science, Industry, and Society. Zürich: ETH Zürich, Umweltnatur- und Umweltsozialwissenschaften. (Published as: Mieg, H.A. (1996). Managing the interfaces between science, industry, and society. In: UNESCO (Ed.), World Congress of Engineering Educators and Industry Leaders (Vol. I, pp. 529-533). Paris: UNESCO.)

UNS-Working Paper 13 (Out of Print)

Scholz, R.W. (1996). Effektivität, Effizienz und Verhältnismässigkeit als Kriterien der Altlastenbearbeitung. Zürich: ETH Zürich, Umweltnatur- und Umweltsozialwissenschaften.

(Published as: Scholz, R.W. (1996). Effektivität, Effi zienz und Verhältnismässigkeit als Kriterien de Altlastenbearbeitung. [Efficacy, efficiency and appropriateness as criteria for evaluating soil remediation cases] In: Baudirektion des Kantons Zürich in Zusammenarbeit mit ETH-UNS (Eds.) Grundsätze, Modelle und Praxis der Altlastenbearbeitung im Kanton Zürich: Referate zur Altlastentagung 1996 [Principles, models and the administrative practice of soil remediation in the Canton of Zurich] (pp. 1-22) Zürich: AGW Hauptabteilung Abfallwirtschaft und Betriebe.)

\section{- UNS-Working Paper 14 (Out of Print)}

Tietje, O., Scholz, R.W., Heitzer, A. \& Weber, O. (1996). Mathematical evaluation criteria. Zürich ETH Zürich, Umweltnatur- und Umweltsozialwissenschaften

(Published as: Tietje, O., Scholz, R.W., Heitzer, A., and Weber, O. (1998). Mathematical evaluation criteria. In H.-P. Blume, H. Eger, E. Fleischhauer, A. Hebel, C. Reij, \& G. Steiner (Eds.), Towards sustainable land use (pp. 53-61). Reiskirchen: Catena.)

ש UNS-Working Paper 15

Steiner, R. (1997). Evaluationsbericht: Bewertung der obligatorischen Berufspraxis im Studiengan Umweltnaturwissenschaften durch Betriebe und Studierende. Zürich: ETH Zürich, Umweltnatur- und Umweltsozialwissenschaften.

- UNS-Working Paper 16 (Out of Print)

Jungbluth, N. (1997). Life-cycle-assessment for stoves and ovens. Zürich. ETH Zürich, Umweltnaturstoves and ovens. Zürich: ETH Zürich,

(Published as: Jungbluth, N. (1997). Life-Cycle-As sessment for stoves and ovens. 5th SETAC-Europe LCAS Case Studies Symposium, (pp. 121-130), Brussels.)

\section{UNS-Working Paper 17}

Tietje, O., Scholz, R.W., Schaerli, M.A., Heitzer, A. \& Hesske, S. (1997). Mathematische Bewertung von Risiken durch Schwermetalle im Boden: Zusammenfassung des gleichnamigen Posters auf der Tagung der Deutschen Bodenkundlichen Gesellschaft in Konstanz. Zürich: ETH Zürich, Umweltnatur- und Umweltsozialwissenschaften.

- UNS-Working Paper 18

Jungbluth, N. (1998). Ökologische Beurteilung des Bedürfnisfeldes Ernährung: Arbeitsgruppen, $\mathrm{Me}$ thoden, Stand der Forschung, Folgerungen. Zürich: ETH Zürich, Umweltnatur- und Umweltsozialwis senschaften.

- UNS-Working Paper 19 (Out of Print)

Weber, O., Scholz, R.W., Bühlmann, R. \& Grasmück, D. (1999). Risk Perception of Heavy Metal Soil Contamination and Attitudes to Decontamination Strategies. Zürich: ETH Zürich, Umweltnatur- und Umweltsozialwissenschaften.

(Published as: Weber, O., Scholz, R.W., Bühlmann, R. \& Grasmück, D. (2001). Risk Perception of Heavy Metal Soil Contamination and Attitudes to Decontamination Strategies. Risk Analysis, Vol. 21, Issue 5, pp. $967-967$.)
- UNS-Working Paper 20

Mieg, H.A. (1999). Expert Roles and Collective Reasoning in ETH-UNS Case Studies. Zürich: ETH Zürich, Umweltnatur- und Umweltsozialwissenschaften.

UNS-Working Paper 21

Scholz, R.W. (1999). "Mutual Learning» und Probabilistischer Funktionalismus - Was Hochschule und Gesellschaft von einander und von Egon Brunswik lernen können. Zürich: ETH Zürich, Umweltnaturund Umweltsozialwissenschaften.

- UNS-Working Paper 22 (Out of Print)

Semadeni M. (1999). Moving from Risk to Action: A conceptual risk handling model. Zürich: ETH Zürich, Umweltnatur- und Umweltsozialwissenschaften.

(Published as: Semadeni, M. (2000). Moving from risk to action: A conceptual risk handling model. In R. Häberli, R. Scholz, A. Bill, \& M. Welti (Eds.), Proceedings of the International Transdisciplinarity 2000 Conference: Transdisiplinarity - Joint Problem-Solving among Science, Technology and Society. ETH Zurich. Workbook I: Dialogue Sessions and Idea Market (pp. 239-234). Zürich: Haffmanns Sachbuch Verlag.)

- UNS-Working Paper 23 (Out of Print)

Güldenzoph, W., Scholz, R.W. (2000). Umgang mit Altlasten während dem Transformationsprozess im Areal Zentrum Zürich Nord (ZZN). Zürich: ETH Zürich, Umweltnatur- und Umweltsozialwissenschaften

(Published as: Güldenzoph, W., Baracchi, C., Fagetti, R., \& Scholz, R.W. (2000). Chancen und Dilemmata des Industriebrachenrecyclings: Fallbetrachtung Zentrum Zürich Nord [Opportunities and dilemmas in the recycling of industrial "brownfields": Case study city center Zurich North]. DISP 143 [Documents and Information on Local, Regional, and Country Planning in Switzerland], 36, 10-17.)

- UNS-Working Paper 24

Semadeni M. (2000). Soil and Sustainable LandUse. Zürich: ETH Zürich, Umweltnatur- und Um weltsozialwissenschaften

\section{- UNS-Working Paper 25}

Sell J., Weber, O., Scholz, R.W. (2001). Liegenschaftsschatzungen und Bodenbelastungen. Zürich: ETH Zürich, Umweltnatur- und Umweltsozialwissenschaften

- UNS-Working Paper 26 (Out of Print)

Hansmann, R., Hesske, S., Tietje, O., Scholz, R.W (2001). Internet-unterstützte Umweltbildung: Eine experimentelle Studie zur Anwendung des OnlineSimulationsspiels SimUlme im Schulunterricht Zürich: ETH Zürich, Umweltnatur- und Umwelt sozialwissenschaften.

(Published as: Hansmann, R., Hesske, S., Tietje, O. Scholz, R.W. (2002). Internet-unterstützte Umweltbildung: Eine experimentelle Studie zur Anwendung des Online-Simulationsspiels SimUlme im Schulunterricht. Schweizerische Zeitschrift für Bildungswissenschaften, Nr. 1/2002.)

- UNS-Working Paper 27

Scholz, R.W., and Weber, O. (2001). Judgments on Health Hazards to Soil Contamination by Exposed and Not-exposed Residents. Zürich: ETH Zürich, Umweltnatur- und Umweltsozialwissenschaften.

- UNS-Working Paper 28

Scholz, R.W., Steiner, R. and Hansmann, R. (2001). Practical Training as Part of Higher Environmental Education. Zürich: ETH Zürich, Umweltnatur- und Umweltsozialwissenschaften.

- UNS-Working Paper 29

Hansmann, R., Scholz, R.W., Crott, H.W., and Mieg, H.A. (2001). Education in Environmental Planning Effects of Group Discussions, Expert Information, and Case Study Participation on Judgment Accuracy. Zürich: ETH Zürich, Umweltnatur- und Umweltsozialwissenschaften.

- UNS-Working Paper 30

Laws, D., Scholz, R.W., Shiroyama, H., Susskind, L., Suzuki, T., and Weber, O. (2002). Expert Views on Sustainability and Technology Implementation. Zürich: ETH Zürich, Umweltnatur- und Umweltsozialwissenschaften. 